\title{
Artukoğulları Beyliği’nin Haçlılar ile Mücadelesine Bir Bakış ${ }^{1}$
}

\author{
Sebahattin ÇELİK²
}

Atıf/C): Çelik, Sebahattin, Artukoğulları Beyliği'nin Haçlılar ile Mücadelesine Bir Bakış , Artuklu İnsan ve Toplum Bilim Dergisi 2020/5 (1), 15-32.

Öz

XII. yüzyılın ilk çeyreğinde, Abbâsî Hilâfeti’nin İslâm ülkeleri ve yöneticileri üzerinde etkisinin kalmadığı bir dönemde, Selçuklu Sultanı Melikşah'ın ölümünün ardından (1092), hanedan üyeleri arasında iktidar kavgaları sürerken, Haçlılar İslâm topraklarını istilâya girişmiş; Urfa (1098), Antakya (1098), Kudüs (1099) ve Trablus'ta (1109) birer devlet kurmuşlardır. Selçuklu Devleti'nin yeterli mücadeleyi gösteremediği, hatta Selçuklu Sultanı Muhammed Tapar'ın Haçlılarla mücadeleden el çektiği bir dönemde tarih sahnesine çıkan Artukoğulları, Haçlılar'a karşı başarılı bir mücadele sergilemişlerdir. Sökmen'in Harran'da (1104), İlgazi'nin Sarmeda Ovası'nda (1119) kazandığı zaferler, Haçlılar'ın yenilmezlik unvanlarını sildiği gibi onların Anadolu ve Suriye topraklarına yerleşmelerinin önünü kesmiştir. Belek Gazi’nin Haçlı liderlerini esir alması ise onların İslâm coğrafyasında tutunmalarını zora sokmuş ve bu topraklardan sökülüp atılmalarının mümkün olabileceğini ortaya koymuştur. Bu çalışmada, ana kaynaklar ve güncel kaynaklar 1şığı altında, Haçlılar'ın İslâm ülkelerinde yayılmalarını önleyebilmek ve onları bu topraklardan söküp atabilmek amacıyla Artuk Bey'in oğulları Sökmen ve İlgazi ile torunu Belek Gazi’nin sergilediği kahramanca mücadeleleri üzerinde durulacaktır.

Anahtar Kelimeler: Sökmen, İlgazi, Belek Gazi, Haçlılar, Harput.

\section{An Overview of the Struggle of Artuqids Principality against the Crusaders}

Citation/C): Çelik, Sebahattin, An Overview of the Struggle of Artuqids Principality against the Crusaders, Artuklu Human and Social Science Journal 2020/5 (1), 15-32.

Abstract

In the first quarter of the twelfth century, in the time of Abbasid Caliphate having no influence, After the death of Seljuk Sultan Melikşah (1092), while the power struggle continued among the dynasty members, the Crusaders invaded the Islamic lands and established a state in Urfa (1098), Antioch (1098), Jerusalem (1099) and Tripoli (1109). Artuquids who came to the stage of history in an environment where the Seljuk state could not fight enough and even Sultan Muhammed Tapar of Seljuks gave up on the conflict against the crusaders, Artuquids fought victoriously against the Crusaders. Artuquids won the victories in Harran of Sukman (1104) and in Sarmeda lowland of İllGhazi (1119). Furthermore, the title of the invincibility of the Crusaders was erased and Artuquids prevented the Crusaders from settling in Anatolia and Syria. Balaq Ghazi captured the Crusaders leaders and he made it difficult for them to live in the Islamic geography and also he showed the leaders that it is probable to expel the Crusaders from the holy land. In the article, under the light of main sources and current sources, they aimed to prevent the Crusaders from spreading on Islamic countries and to expel them from these lands. Therefore, the heroic struggles of Artuk Bey's sons Sukman and IIl-Ghazi and grandson Balaq Ghazi will be emphasized.

Keywords: Sukman, Ill-Ghazi, Crusaders, Harput.

1 Bu çalıșma, 11-13 Kasım 2005’te Celal Bayar Üniversitesi tarafından düzenlenen “II. Uluslararası Türk Tarihi ve
Edebiyatı Kongresi” nde sunulan tebliğin genişletilmiş ve güncellenmiş hali olup hiçbir yerde yayınlanmamıștır.
${ }^{2}$ Dr., Aile, Çalışma ve Sosyal Hizmetler Müdürlüğü, Elazığ, sebahattin_celikcbu@hotmail.com, ORCID: orcid.org/0000-0003-0300-0113.

Geliş/Received: 20.02.2020, Kabul/Accepted: 13.07 .2020 


\section{GİRIŞ}

Bu makale, tarih literatürümüzde adından yeterince söz edilmediğini düşündüğümüz Artuk Bey, Sökmen, İlgazi ve Belek Gazi hakkında kapsamlı bir literatür taraması sonucunda, güncel ve ana kaynaklar ışığında önemli bilgilerin derlendiği nitel bir çalışmanın ürünü olarak ortaya konulmuştur. Çalışmada, Haçlılar'ın 1097 yılından itibaren İslâm topraklarında yayılmaya başladıkları, onları durdurmakta yetersiz kaldığı görülen Selçukluların 1115 yılından sonra kendi iç meseleleri ile uğraştıkları, bu süreçte yerel bir beylik olarak tarih sahnesine çıkan Artuklular'ın Haçlılar'a karşı sergiledikleri başarılı mücadeleleri ve bunun sonucunda Haçlılar'ın Doğu ve Güneydoğu Anadolu yönünde ilerlemelerinin önünü alabildikleri gerçeğine dikkat çekilmesi hedeflenmiştir. Çalışmanın ana gövdesinde çoğunlukla siyasî gelişmelere yer verilmiş, yorum ve değerlendirmeler sonuç bölümünde ele alınmıştır.

Haçlı Seferleri, papalığın girişimleriyle Avrupalı Hıristiyanların Müslümanları Avrupa'dan kovmak, Türklerin batıya doğru ilerleyişini durdurmak, Orta Doğu'yu ve kutsal toprakları ele geçirmek maksadıyla İslam dünyasına karşı tertip ettikleri savaşlar silsilesinin genel adıdır. Sefere katılanlara giysilerine haç işareti taktıkları için yerli ve yabancı tarihçiler tarafından Haçlılar, Ehl-i Salîb, Salibiyyûn, Franklar ve Crusades gibi isimler verilmiştir. En önemlisi dinî olmak üzere, siyasî, sosyal ve iktisadî sebeplere dayanan Haçlı Seferleri'ni Papa II. Urbanus, 1095 yılında düzenlediği Klermont Konsili'nde yaptığı konuşmayla başlatmıştır. Literatürde Haçlı Seferleri olarak adlandırılan bu seferler, batılıların son Haçlı merkezi olan Akkâ'yı kaybetmelerine kadar (1291) yaklaşık iki yüzyıl süren dokuz büyük seferi kapsamaktadır. 1096 yılında başlayıp, günümüze kadar kanlı savaşlar silsilesi halinde devam edegelen ve milyonlarca can kaybına sebep olan Haçlı Seferleri, aynı zamanda Doğu ile Batı arasında ilmî, içtimaî, askerî ve ekonomik farklılıkların da artarak süregelmesine sebep olmuştur. Hıristiyan Batı'nın XI. yüzyıldan başlayarak İslâm ülkelerine karşı tatbik ettiği yayılmacılık ve sömürgecilik hareketleri, günümüzde farklı bir boyut kazanarak sıcak savaşın yanı sıra soğuk savaş (siyasî, ekonomik, teknolojik, kültürel vb. ambargolar) olarak da varlığını sürdürmektedir. Görünen o ki Hıristiyan Batı, dokuz asır önce gözlerini diktiği Orta Doğu topraklarından hiçbir zaman vazgeçmeyecektir.

Malazgirt Muharebesi'nin ardından Artuk, Saltuk, Danişmend, Mengücük, Çavuldur ve Çaka (Çakan) ismindeki Türkmen beylerinin Anadolu'yu fethe girişmeleri ve ele geçirdikleri bölgelerde kendi adları ile anılan birer beylik kurmaları, Bizans'ı ve dolaylı olarak Avrupa'yı derin bir endişeye sevk etmişti. Bizans imparatorluk tahtını ele geçiren I. Aleksios Komnenos (10811118), Türkleri durduramayacağını anlayınca 1095 yılında Papa II. Urbanus’tan Türklere karşı Avrupa'dan ücretli asker temin etmesini istemişti (Runciman, 1992/I: 80-82; Bailly, 2006: 307; Sevim, 1990: 46-71). Bu sırada Selçuklular, 1092 senesinde ünlü vezirleri Nizamü'l-Mülk ve Ebû'lFeth unvanıyla tanınan büyük sultanları Melikşâh'ın birer suikast ile öldürülmelerinin ardından bir kaos içerisine sürüklenmiş; Melikşâh'ın kardeşi (Tacu'd-Devle Tutuş), hanımı (Terken Hatun) ve oğulları (Berkyaruk, M. Tapar, Sencer) arasında saltanat mücadelesi başlamıştı (Müneccimbaşı, 2001/II; Alptekin, 1992; Özaydın, 1990; Merçil, Ankara 1999: 83-90; Alptekin, 1992: 150 vd; Köymen, 1982: $287 \mathrm{vd}$ ). Bizans imparatorunun teklifi üzerine uzun uzun düşünen ve Türkler arasında yaşanan çatışmalardan kaynaklanan otorite boşluğunu da göz önünde bulunduran Urbanus, Avrupa'nın açlık, sefalet ve yükselen suç oranları ile feodal yapıdan dolayı canından bezmiş olan halklarını, "Tanrı adına savaş" megalo ideası uğruna İslâm dünyası üzerine gönderebilmenin mümkün olabileceğine karar vermişti. O, işgal ettiği papalık makamını bir taraftan Hıristiyan krallarla Doğu'daki Ortodoks, Süryani ve Ermeniler üzerinde yegâne dinî otorite olarak kurmanın, diğer taraftan "kâfir" Türkleri Anadolu'dan söküp atmanın, Hıristiyanlar tarafından kutsal sayılan yerleri ele geçirmenin ve böylece Hz. Îsâ'yı memnun edebilmenin planlarını yapmaya başlamıştı (Anna Komnena, 1996: 206; Demirkent, 1997: 5 vd.). Nitekim Papa II. Urbanus 27 Kasım 1095'de Fransa'da düzenlediği Klermont Konsili'nde Avrupa halklarına: “zengin doğuya gitmeleri 


\section{S. ÇELIK}

durumunda para ve toprak sahibi olacaklarını, kâfirlerin baskısı altında zulüm gören din kardeşlerini kurtarmanın dinî bir görev olacağını, İsa aşkına onun mezarını kurtarmanın kutsal bir iş olacağını..." anlatmıştı (Papa'nın nutku için bkz. Fulcherios Carnotensis, 2009: 50-52; Lamb, 2010: 5-6). Papa'nın görevlendirdiği vaizler Avrupa'nın en ücra köşelerine kadar giderek, yaptıkları ateşli konuşmalarla eli silah tutan herkesi kutsal savaşa davet etmiş, insanlar bu çağrıya beklenmedik bir katılım göstererek; evlerini, arazilerini, hayvanlarını, hatta yiyecek ve giyeceklerini yok pahasına satarak tek umut olarak gördükleri seferin hazırlıkları yapmaya başlamışlardı. Sefere katılmak istemeyenler veya sefere gidecek durumda olmayıp bulunduğu çevrenin kilisesine vergisini vermeyenler ise Hıristiyanlıktan aforoz edilmişlerdi (Runciman, 1992/I: 65 vd).

\section{Haçlı Seferleri'nin Başlaması}

Almanya'da çoğunluğu tarım sınıfından oluşan yaklaşık 30.000 kişilik bir orduyu kendi girişimleriyle kurmaya muvaffak olan münzevi Keşiş Pierre l'Ermitte, Haçlı ordularının öncüleri diyebileceğimiz bu ordunun başında 1096 yılı yazında Anadolu topraklarına girdi. Ancak bu düzensiz güruhlar Selçuklu Sultanı I. Kılıç Arslan'ın kuvvetleri tarafından 21 Ekim 1096 tarihinde İznik yakınlarında yok edildiler. Ertesi yıl Avrupa'dan yüzbinlerle ifade edilen düzenli ordular Anadolu'ya girerek İznik önlerine gelip Anadolu Selçuklu Devleti'nin başkentini kuşattılar. Bu sırada Malatya'nın fethi ile uğraşan I. Kılıç Arslan, süratle geri döndüyse de kendi kuvvetlerinden sayıca çok fazla olan Haçlı kuvvetlerine karşı bir başarı elde edemedi. 19 Temmuz 1097'de İznik garnizon komutanı şehri teslim etmek zorunda kaldı (Mateos, 1987: 190; Anna Komnena, 1996: 324-325; Eyice, 2001: 543-545). İznik'i antlaşma gereği Bizans imparatoruna bırakan Haçlılar, Antakya'ya doğru yola çıktılar. Bu arada Kılıç Arslan da Danişmentliler beyliği ile ittifak ederek Haçlılar'ın güzergâhları üzerinde bulunan köyleri boşalttırdı. Tarlaları ve su kuyularını tahrip ettirerek onları açlık ve susuzluğa mahkûm ettikten sonra Eskişehir (Dorylaion) yakınlarında Haçlılar'a karşı büyük bir saldırı düzenledi. Türklerin bu saldırısı her ne kadar beklenen başarıyı getirmediyse de Türk okçuları Haçlılar’a büyük kayıplar verdirmeye muvaffak oldular. Güçlükle Çukurova'ya ulaşabilen Haçlılar, burada yerli Ermeni halktan askerî ve ekonomik yardım görerek Maraş, Adana ve Tarsus'u ele geçirdiler (Azîmî, 1988: 30; Mateos, 1987: 192-193; Runciman 1992/I: 136-141; Özaydın, 1992: 121-138). Bu esnada Urfa Hâkimi Toros'un elçileri gelerek Haçlılar'ı Urfa'ya davet ettiler. Davete olumlu cevap veren Kont Baudouin, Haçlı ordusundan ayrılarak emrindeki askerleri ile Urfa'ya gitti ve 10 Mart 1098'de Urfa Haçlı Kontluğu'nu kurdu (Demirkent, 1990: $29 \mathrm{vd}$ ).

Çukurova'dan hareket eden esas Haçlı ordusu 20 Ekim 1097'de Antakya'yı kuşattı (Azîmî, 1988: 30; Mateos, 1987: 190-195; İbnü'l-Esîr, 1987/X: 225-229; İbnü'l Adîm, 1954/II: 129). Büyük Selçuklu Sultanı Berkyaruk, Antakya Valisi Yağısıyan'a yardım etmek üzere Musul Emîri Kürboğa'yı görevlendirdi. Ancak Kürboğa, Urfa'yı teslim almak için zaman harcarken, Antakya Haçlılar'ın eline geçmiş oldu. Selçuklu ordusunun Antakya'yı sıkı bir kuşatma altına alması karşısında şiddetli kıtlık yaşayan Haçlılar, şehri Müslümanlara teslim edip ülkelerine geri dönmek istedilerse de Kürboğa bunu kabul etmedi (İbnü’l Adîm, 1954/II: 136-137). Tüm ümitlerini kaybettikleri sırada, Hz. Îsâ’nın böğrünü delen mızrağın bulunduğu haberi ile maneviyatı yükselen Haçlılar, 28 Haziran 1098 sabahı Müslümanların üzerine saldırıya geçtiler. Kürboğa'nın ordusu üzerlerine gelen Haçlılar'ı durduramadı. Müslümanların bozulup dağılmalarının ardından, Antakya Haçlı Prinkepsliği kurulmuş oldu (Mateos, 1987: 197; İbnü’l-Esîr, 1987/X: 231).

Antakya'nın sükûtunun ardından Haçlılar, 1098 yılının Temmuz ayında Tell-Mannas'ı, Eylül'de Azaz'ı ve el-Bâre'yi, Kasım'da Maarratu'n-Nûmân'1 ele geçirip bu kentlerde katliam ve yağma yaptılar. Ocak 1099'da Kudüs'e doğru harekete geçtiklerinde Hamâ, Humus emirleri, Şeyzer'deki Munkızîler ve Trablus Benî Ammâr Kabilesi, kendilerine dokunmamaları karşılığında Haçlılarla yiyecek, yük hayvanı ve kılavuzluk konusunda anlaştılar. Bukayye Vadisi yolunu izleyen 
Haçlılar Refeniyye, Hisnu'l-Ekrâd (Kürtlerin Kalesi) ve Tartûs'u ele geçirdiler. Tartûs'un alınmasıyla Haçlılar için Antakya, Kıbrıs ve Avrupa'ya denizden ulaşım yolu açılmış oldu (Azimî, 1988: 32; İbnü'l-Esîr, 1987/X: 232; Ebû'l-Ferec, 1999/II: 341; Runciman 1992/I: 198-200). Burada İngiliz ve Ceneviz filolarıyla irtibat kurarak Haçlılar, sahil yolundan Fâtımî sınırını aşıp Beyrut, Sûr ve Akkâ valileri ile öncekilere benzer birer anlaşma yaptılar. 3 Haziran'da Remle'yi ele geçirdikten sonra yollarına devam eden Haçlılar, 7 Haziran 1099'da Kudüs önlerine gelip karargâhlarını kurdular (Mateos, 1987: 199; Azîmî, 1988: 31-32; Ebû'l-Ferec, 1999/II: 341; Runciman, 1992/I: 199-214; Demirkent, 1997: 30 vd; Sevim, 1989: 189-192; Holt, 1999: 22, 23). 15 Temmuz 1099 günü Kudüs surlarını aşan Haçlılar, Dâvûd Kulesi'ne sığınan Fâtımîlerin Valisi İftiharu'd-Devle'nin büyük miktarda altın vermesi üzerine sadece onu ve beraberindekileri sağ bıraktılar (Anonim Süryâni, 1933: 73). Kudüs'te öldürülenlerin sayısı kesin olarak bilinmemekle beraber, bilinen şeyin üç gün boyunca kadın çocuk demeden herkesin kılıçtan geçirildiği, Yahudilerin de sığındıkları Havraları ile beraber ateșe verildikleridir (Mateos, 1987: 199; Ebû'l-Ferec, 1999/II: 341; Refik, hicri 1327: 23). Haçlılar, Kudüs'ü ele geçirdikten sonra Kudüs'ün yöneticiliğine 'Kutsal Mezarın Savunucusu" unvanıyla Godefroi de Boullion'u seçtiler. Ardından üzerlerine gelen Mısır Fâtımî ordusunu Askalân (12 Ağustos 1099)'da bozguna uğrattılar. Bu zaferin ardından bütün Filistin şehirlerini kolayca işgal ettiler ve Kudüs Haçlı Devleti'ni kurdular. (Mateos, 1987: 199-200; Azîmî, 1988: 32-33; İbnü'l-Esîr, 1987/X: 235-237; Ebû'l-Ferec, 1999/II: 340-341; Refik, hicri 1327: 23; Runciman, 1992/I: 215-221; Demirkent, 1997: 51-60; Holt, 1999: 22- 23).

Birinci Haçlı Seferi’nin hedefine ulaşması üzerine Avrupa'dan tarihçilerin "1101 Yılı Haçlı Seferleri” diye adlandırdıkları Fransız, Alman ve Lombardlardan oluşan üç büyük Haçlı ordusu ile daha Anadolu'ya girdi. Ancak bu kez karşılarında, Türk beyleri ile ittifak ederek ordusunu güçlendiren Sultan I. Kılıç Arslan'1 buldular. Lombard ordusu Merzifon'da (5 Ağustos 1101), Fransız ordusu Konya'da (13 Ağustos 1101), Alman ordusu da Ereğli'de (5 Eylül 1101) Türkler tarafından yok edildiler. Bu mücadeleler esnasında Artuk Bey’in torunu Belek b. Behrâm, I. Kılıç Arslan'ın yanında yer alarak Haçlılar'ın hezimetinde büyük rol oynadı (Mateos, 1987: 216-219; Azîmî, 1988: 33, 101; Runciman, 1992/II: 15-25; Demirkent, 1995: 28; Y1ld1z, 1990: 286). Anadolu topraklarını hedeflemiş olan bu Haçlı Seferi, onların asıl niyetlerinin kendilerine bu coğrafyada birer krallık tesis etmek olduğunu ortaya koymuştur. Türklerin bu üç büyük Haçlı ordusu karşısında sergiledikleri başarı, Anadolu Türklerinin bu topraklarda kalıcı olarak tutunacaklarını göstermiş, Suriye-Filistin topraklarında Haçlılar'a karşı direnen Müslümanlara rahat bir nefes aldırmış, diğer taraftan Aleksios ile Haçlılar arasındaki ittifakın çatırdamasına sebep olmuştur.

1101 yılında Merzifon'da hezimete uğrayan Haçlı ordusuna liderlik eden, Haçlı liderleri arasında en nüfuzlu kişi olan IV. Raymond de Saint Gilles, kendisine bir devlet kurabilmek amacıyla Trablus'u zapt etmeye karar verdi. O, Şubat 1103'te Lataika (Lâzikiye) Limanı'na gelen Ceneviz filosunun desteği ile Trablus üzerine yürüdü. Trablus'a yardıma gelen Humus ve Dımaşk kuvvetlerini yenmesine rağmen şehri ele geçiremedi (İbnü'l-Adîm, 1954/II: 130; Runciman, 1992/II: 48). Raymond iki yıllık kuşatmanın ardından 28 Şubat 1105'te bir yangında yaralanıp ölünce, yerine kuzeni Cerdagne Kontu Guillaume Jourdain geçti. Trablus ablukası şiddetlenince, Trablus Emîri Ebû Alî, Mardin'deki Artukoğlu Sökmen'den yardım istedi. Ancak ona yardım için yola çıkan Sökmen, Dımaşk yakınlarında Tedmür'de vefat etti (Azîmî, 1988: 34). 1108 yazında Raymond'un oğlu Bertrand, Toulous'tan yola çıkarak Cenova'ya geldi. Cenevizlilere Trablus'ta ticarî imtiyaz vereceğini vaat ederek altmış gemiden müteşekkil Ceneviz donanmasının desteği ile Haziran 1109'da Trablus'u ulaştı. Kumandayı Jourdain'in elinden aldı ve şehri denizden kuşattı. 1100 yılında ağabeyi Godefroi'un ölmesi üzerine Kudüs Kralı olan I. Baudouin'den de destek alarak Trablus kuşatmasını sıkılaştırdı. Yedi yıllık kuşatmadan sonra, 12 Temmuz 1109'da Trabluslular şehri antlaşma yoluyla teslim etmek zorunda kaldılar. Bundan sonra Bertrand'ın hâkimiyetinde Trablus Haçlı Kontluğu kurulmuş oldu. Bu dört Haçlı devletine "Denizaşırı Ülke” anlamına gelen 
Outremer adı verildi (Mateos, 1987: 228, 229-237; Azîmî, 1988: 34-36; İbnü’l-Esîr, 1987/X: 280297,315-332; İbnü'l Adîm, 1954/II: 130; Ebû'l-Ferec, 1999/II: 343,350; Runciman, 1992/II: 46-57; Holt, 1999: 25-29,32; Demirkent, 1997: 99 vd; Küçüksipahioğlu, 2007: 77)

\section{Artukluların Tarih Sahnesine Çıkması}

Artuklu Beyliği’nin kurucusu Zahirüddin Artuk b. Eksük’ün, Oğuzların Kayı veya Döger boyundan olduğuna dair ihtilaflı görüşler vardır (Yınanç, 1944: 139; Sevim, 1962:121-146; Artuk, 1988:1). Babası Eksük'ün, ölümünden sonra obanın beyi olan Artuk, 1063 yılında Azerbaycan'da bütün kabilesi ile birlikte Sultan Alparslan'ın hizmetinde yer almış, onun en güzide kumandanlarından biri olarak tarihe adını yazdırmıştır. Tarihçiler onu girdiği her savaştan muzaffer çıkan emir olarak kaydetmişlerdir (İbnü’l-Esîr, 1987/X: 135; Sevim, 1962: 123-124). 26 Ağustos 1071'deki Malazgirt Savaşı'ndan sonra, Bizans'ın antlaşma şartlarını yerine getirmemesi üzerine Alparslan, ileri gelen kumandanları gibi Emir Artuk'u da Anadolu'nun fethi ile görevlendirmişti. Kızılırmak ile Yeşilırmak arasındaki Orta Anadolu'nun fethini kısa zamanda tamamlayan Artuk Bey, buradan İzmit'e kadar ilerleyerek Bizans'ın iç işlerine dahi müdahale edebilecek bir kudrete ulaşmıştı. O, 1072 yılında Selçuklu tahtına oturan Melikşâh ile amcası Kavurd'un saltanat mücadelesinde Anadolu'dan Hemedan'a gelerek Melikşâh'ın galibiyetinde önemli rol oynamış, 1076 yılında Sultan Melikşâh tarafından bu kez Karmatîleri itaat altına alma ve Doğu Arabistan'ın fethi ile görevlendirilmiştir (İbnü’l-Cevzî, 1992: 17; Mateos 1987: 168-169). Sultanın verdiği görevleri başarı ile yerine getiren Artuk Bey, kendisini çekemeyen diğer emirler yüzünden 1085 yılında Suriye-Filistin Meliki Tacu'd-Devle Tutuş'un hizmetine girmiş, bu süreçte Anadolu Selçuklu Sultanı Süleymanşâh'ı Halep yakınlarındaki yenilgisinde önemli katkıları olunca elCezire'deki bazı topraklar ile Kudüs ve civarı kendisine iktâ olarak verilmiştir (Sevim, 1991: 414). Anadolu topraklarının ardından Kudüs'te ikinci kez bir beylik tesis eden Artuk Bey, şehirde asayiş ve huzur sağlamıştır. Onun 1091 yılındaki vefatının ardından yerine oğulları Sökmen ve İlgazi geçmiş ancak onlar buradaki beyliklerini fazla sürdürememişlerdir (İbnü'l-Ezrak, 1992: 29-30; Alptekin, 1991: 415-419). Zira Haçlılar'ın Avrupa'dan İslâm coğrafyası üzerine harekete geçtikleri sırada (1096), Mısır Fâtımî ordusu Kudüs önlerine gelerek şehri kuşatma altına almış, 40 gün boyunca kuşatmaya direnen Artukoğulları, sonunda şehri Fâtımîlere terk edip el-Cezire'deki topraklarına çekilmek zorunda kalmışlardır (Turan, 1980: 135-136; Sevim, 1962: 501-520).

\section{Sökmen B. Artuk}

Artuk Bey'in büyük oğlu Muînüddîn Sökmen Kudüs'ün kaybedilmesinden sonra Halep’e gelmiş, Haçlılar henüz bölgeye gelmeden önce Halep Meliki Rıdvan'ın yanında yer alarak kardeşi Dukak ile Kınnesrin'de yapılan savaşta galip gelmesinde önemli rol oynamışı (1097). Bunun üzerine Rıdvan tarafindan kendisine Maarratu'n-Nûmân iktâ olarak verilmişti (İbnü'l Adîm, 1954/II: 126; Nuveyrî, 1992/XXVII: 72). Sökmen, Maarratu'n-Nûmân'a giderken yeğeni Belek'i de Tutuş zamanında kendilerine iktâ olarak verilmiş olan Suruç'un yönetimine atamıştı (Sevim, 1989: 163-164; Alptekin, 1991: 415). Bu sırada bölgedeki Türk beylerine Haçlılar'ın Anadolu'ya girip İznik'i ele geçirdikleri ve Antakya'ya doğru ilerledikleri haberleri gelmişti. Türk emirler derhal aralarında toplanıp bir durum değerlendirmesi yapmış, Sökmen bu toplantıda Haçlılar'ın Diyarbakır sınırlarında karşılanıp durdurulması gerektiğini önermişti. Ancak diğer emirler sonradan pişman olacakları önemli bir yanlış yaparak onun önerisini kabul etmemişlerdi (Sevim, 2009: 392).

Nitekim Haçlılar hiçbir direnişle karşılaşmadan Antakya önlerine kadar gelebildiler. Sökmen ve yeğeni Belek 1098 yılı Haziran ayında Antakya'yı Haçlılar'dan geri almak için Musul'dan gelen Kürboğa komutasındaki Selçuklu ordusuna katıldılar. Antakya önlerinde Haçlılar'a karşı başarıı mücadele sergileyen Sökmen, Selçuklu ordusunun bozulması üzerine o da kuvvetlerini geri çekmek zorunda kaldı. Yeğeni Belek ile Temmuz ayında Suruç'a geri döndüklerinde buradaki yerli Hıristiyanların şehri Urfa Kontu Baudouin'e teslim ettiklerini, Baudouin'in de burayı Foucher de 
Chartres (Foulque de Chartes)'in kumandasına verdiğini gördüler (İbnü'l-Esîr, 1987/X: 266; İbnü'l Adîm, 1954/II: 203). Muhtemelen o günlerde Suruç'u Haçlılar'dan geri alacak kuvvete sahip olmayan Sökmen ve Belek, buradan Kudüs'e giderek Haçlılar'ın ana hedefi olan bu kutsal şehrin savunma tedbirlerini aldılar. Ancak bu sırada Haçlılar'dan önce Fâtımî tehdidi ile karşı karşıya kaldılar. Türklerin içinde bulundukları kaostan faydalanmak isteyen Fâtımî Veziri el-Efdal Şâhenşâh, Mısır ordusunun başında Kudüs önlerine gelerek şehri kuşattı (İbnü’l-Esîr, 1987/X: 236; Runciman, 1992/I: 220 vd; Turan, 1980: 135-136; Sevim, 1962: 502). Kudüs'ü Fatımîlere teslim etmek zorunda kalan Artukoğulları, yapılan anlaşma gereği ailelerini ve askerlerini alarak buradan Kuzey Suriye'ye kendilerine iktâ olarak verilmiş olan topraklarına geri döndüler. Bir süre sonra gücünü toparlayan Sökmen, Ocak 1101'de yeğeni Belek ile birlikte Suruç'u Haçlılar'dan geri almak üzere harekete geçti. Şehrin Hâkimi Foucher de Chartres derhal Urfa'nın yeni kontu II. Baudouin'den yardım istedi. Artuklu kuvvetleri Foucher'in kuvvetlerini ve ona yardıma gelen Haçlılar'ı feci bir hezimete uğrattılar. Bu savaşta Foucher hayatını kaybederken, Kont Baudouin de canını zor kurtarıp beraberinde üç şövalyesiyle Antakya'ya kaçtı. Artuklular zafer kazanıp Suruç'a girince, şehirdeki gayrimüslim tebaa, Urfa Latin Başpiskoposu Benedictus'un kumandasında iç kaleye sığınıp burayı savunmaya başladı. Bir süre sonra Kont Baudouin, Antakya'dan temin ettiği büyük bir Haçlı ordusu ile Suruç’a geri döndü. İç kaleden huruç eden Ermeniler ile Antakya Haçlı ordusu arasında kalan Sökmen ve Belek, daha fazla direnemediler ve şehri Haçlılar'a bırakıp geri çekilmek zorunda kaldılar (Mateos, 1987: 206 vd; Azimî, 1988: 32,38; İbnü'l-Esîr, 1987/X: 267; İbnü'l Adîm, 1954/II: 203; Ardıçoğlu, 1964: 37-38; Sevim, 1962: 508 vd.).

Suruç’u kaybettikten sonra Belek, Anadolu Selçuklu Sultanı I. Kılıç Arslan'ın çağrısı üzerine, Artuklu birliğinin başında Çankırı'ya giderek yukarıda kısaca bahsettiğimiz "1101 Yılı Haçlı Seferleri”ne katıldı. Burada gösterdiği cesaret ve kahramanlığı ile sultanın takdirini kazandı (İbnü'l- Kalânisî, 2015: 7; Ebû'l-Ferec, 1999/II: 351; Turan, 1980: 152 vd.; Demirkent, 1996: 3740). Anadolu'ya giren üç Haçlı ordusunun imha edilmesinden sonra amcası Sökmen'in yanına döndü. 1102 yılında Sökmen yeğeni ile birlikte, el-Cezire Emîri Çökürmüş ile Musul Emîri Mûsâ arasındaki savaşta Mûsâ'nın yardımına koştu ve kazanılan zaferin ardından kendisine vaat edilen Hısn-1 Keyfâ (Hasankeyf)'yı teslim aldı. Hısn-1 Keyfâ'ya hâkim olan Sökmen, burada yeni bir Artukoğulları Hükümdarlığı'nın temellerini attı (İbnü'l-Esîr, 1987/X: 280, 316; İbnü'l-Ezrak, 1992: 30; Sevim, 1962: 511-512). 1103 yılında Mardin'i ele geçiren yeğeni Yakutî’nin ölmesi üzerine Sökmen, Mardin'e gelerek buranın yönetimini de uhdesine aldı (İbnü'l-Esîr, 1987/X: 124).

1104 yılı ilkbaharında Antakya Prinkepsi Bohemund ve Tell-Bâşir (Turbessel-Tılbaşar) Hâkimi Joscelin de Courtenay, el-Cezire'deki Müslümanlar üzerine saldırılarını yoğunlaştırdılar. Maraş’ı ele geçirdikleri gibi Mardin ve Harran'da yaşayan Türkler üzerine saldırıp mallarını yağmalamaya başladılar. Bu gelişmeler üzerine Sökmen ve Musul Atabeyi Çökürmüş, Haçlılar'1 durdurabilmek amacıyla aralarındaki Mardin'in hâkimiyeti yüzünden yaşanan ihtilafı sonlandırıp güçlerini birleştirdiler (İbnü'l-Kalânisî, 2015: 14; İbnü'l-Esîr, 1987/X: 303; Nuveyrî, 1992/XXVII: 72; Runciman, 1992/II: 32-34). Türklerin ittifakını haber alan Urfa Kontu Baudouin, Tell-Bâşir Hâkimi Joscelin, Suruç Hâkimi Benedictus, Antakya Prinkepsi Bohemund ve yeğeni Tankred Türklere karşı güç birliği edip Harran'a doğru yola çıktılar. Haçlı kuvvetleri Harran Ovası'nda Belih Çayı yakınlarında 7 Mayıs 1104 günü, Türklerin savaş tuzağına düşerek kılıçtan geçirildiler. Ele geçen esirler arasında Baudouin ile Joscelin de vardı. Haçlılar'ın artçı kuvvetlerinin başında bulunan Bohemund ve Tankred ise savaşa iştirak etmediler ve Urfa'yı savunmak üzere savaş bölgesinden geri çekildiler (Mateos, 1987: 252; İbnü'l-Esîr, 1987/X: 303-304; Runciman, 1992/II: 32-33; Kütük, 2018: 164). Bu savaş bölgede üstünlük kurmaya çalışan Haçlılar'a karşı vurulan önemli bir darbe oldu. Zira bu hezimetin ardından Haçlılar'ın bölgedeki yayılmalarının önüne geçildiği gibi onların faaliyet alanları da daraltılmıştı. 
Türklerin zaferine rağmen Sökmen'in ordusu ganimet peşine düşmemiş, Bohemund ve Tankred'in askerlerini takip ediyordu. Bu sırada Çökürmüş’ün adamları, Sökmen'in çadırında esir tutulan Kont Baudouin'i kaçırmış, Çökürmüş'e teslim etmişlerdi (İbnü'l-Esîr, 1987/X: 267; Müneccimbaşı, 2001/II: 169). Bundan sonra Artukoğlu Sökmen kendi çadırından Baudouin'i kaçıran Çökürmüş ile ittifaktan vazgeçti. Askerlerini "Müslümanların bu gazâdan duydukları sevinç, bizim aramızdaki karışıklıktan dolayı kedere dönmesin!” diyerek yatıştırdı. Ardından Haçlılar ile cihadına devam edip civardaki bazı kaleleri onların elinden aldı ve daha sonra Mardin'e döndü (Sevim, 1962: 518). Çökürmüş ise Harran üzerine yürüyerek burasını Haçlılar'ın elinden aldı. Ardından Urfa üzerine yürüdüyse de burada bir başarı elde edemeden yanında bulunan Harran savaşının esirleri ile birlikte Musul'a geri döndü (Mateos, 1987: 223-224; Azîmî, 1988: 34; İbnü'lEsîr, 1987/X: 267; İbnü'l Adîm, 1954/II: 155; Müneccimbaş1, 2001/II: 167-169; Demirkent, 1997: 75). Bu aşamanın ardından Sökmen, Trablus Emîri Ebû Alî’nin yardım çağrısına olumlu cevap vererek, Trablus'u Haçlılar'ın kuşatmasından kurtarmak üzere kuvvetlerinin başında sefere çıktı. Ancak Fırat'ı geçip Dımaşk yakınlarındaki Tedmür beldesine vardığında amansız bir difteri hastalığına yakalanarak bir süre sonra burada vefat etti. Oğlu İbrahim ve yeğeni Belek onun naaşını alarak Hısn-1 Keyfầya geri döndüler. Onun ölümünden sonra oğlu İbrahim, Hısn-1 Keyfầ ve Mardin'in hükümdarı oldu. Yeğeni Belek ise diğer amcası İlgazi'nin yanına giderek onun maiyetine girdi (İbnü'l-Kalânisî, 2018: 18-19; Mateos, 1987: 225; Azimî, 1988: 34; İbnü'l-Esîr, 1987/X: 315316; Müneccimbaş1, 2001/II: 168-169).

\section{1. İlgazi B. Artuk}

Artukoğulları 1098 yılında Kudüs'ten ayrılmak zorunda kaldıklarında Sökmen, Halep Melik'i Rıdvan'ın maiyetine girerken, kardeşi Necmeddin İlgazi, bu sırada ağabeyi Berkyaruk'a karşı Büyük Selçuklu Sultanlığı'nı ilan eden Muhammed Tapar'ın maiyetine girmişti. Muhammed Tapar bu değerli komutanına Hulvan'1 ve Sincar'ı iktâ olarak vermişti (İbnü'l-Ezrak, 1992: 30). 1102 yılına gelindiğinde ise halifenin onayını aldıktan sonra Bağdat'a giren Muhammed Tapar, bölgede hutbeleri kendi adına okutmaya başlamış, Bağdat şahnesi Cevherâyin'i görevinden azledip yerine İlgazi'yi atamışt. Bir yıl sonra Berkyaruk'un Bağdat'ı ele geçirmesi üzerine İlgazi, hutbeleri bu kez çaresiz onun adına okutmuş ve bu yüzden de Muhammed Tapar'ın öfkesini üzerine çekmişti (İbnü'l-Esîr, 1987/X: 329-337; Sevim, 2000: 89).

1104 yılında Berkyaruk genç yaşta vefat edince, Büyük Selçuklu Devleti tahtına Muhammed Tapar oturdu. Muhammed Tapar'ın emriyle Bağdat şahneliğinden azledilen İlgazi, Sökmen'in oğlu İbrahim'in yönetimindeki Mardin'e gidip buranın idaresini uhdesine aldı ve burada Mardin Artukluları Emirliği’ni kurdu (İbnü’l-Ezrak, 1992: 31; Azimli, 2008: 15). Büyük Selçuklu Sultanı olan Muhammed Tapar, bölgedeki Haçlılar'ı İslâm topraklarından söküp atmak üzere Musul Atabeyi Mevdûd b. Altuntekin'i görevlendirdi. Bölgedeki emirlere de birlikleri ile Mevdûd'un ordusuna katılmalarını emretti. Sultanın emri üzerine Ermenşah adıyla ün kazanan Meyyâfârikîn (Silvan) ve Tebriz Emîri Sökman el-Kutbî, Azerbaycan'da Urumiye Gölü’nün doğusunda bulunan Meraga şehrinin Kürt Emîri Ahmedil, Mardin Emîri Artukoğlu İlgazi ve yeğeni Belek kuvvetleriyle Mevdûd'un ordusuna katıldılar (İbnü'l-Kalânisî, 2018: 42; İbnü'l-Esîr, 1987/X: 390; Runciman, 1992/II: 95 vd). Onların kuvvetleriyle daha da güçlenen Mevdûd, 1110 yılı Nisan ayında komuta ettiği Selçuklu ordusuyla Urfa üzerine yürüdü. Bu ittifakı haber alan Urfa Kontu Baudouin, Kudüs Kralı I. Baudouin'den acil yardım istedi. O sıralarda Beyrut'u kuşatmakta olan Kral Baudouin, Beyrut'un kuşatmasını kaldırıp Haziran 1110'da kuzeye Urfa'ya doğru hareket etti. Yolda Keysun Ermeni Prensi Kogh Vasil ile Ermeni Pehlavuni kabilesinin reisi Birecik Hâkimi Ebû'l-Garip de kuvvetleriyle ona katıldılar. Mevdûd, Kudüs Haçlı kuvvetlerinin üzerlerine geldiğini haber alınca, onları pusuya düşürmek gayesiyle Fırat'ın doğusuna Harran'a çekildi. Amacı açık alanda Haçlı ordusunu kuşatıp imha etmekti (İbnü'l-Kalânisî, 2018: 42; Mateos, 1987: 239; Runciman, 1992/II: 95). Haçlı kuvvetleri Refeniyye'yi ele geçirdikten sonra Mevdûd'u takibe başladılar, Harran'daki 
Şinav Kalesi'ni kuşattıkları sırada Mevdûd'un planını fark edip aniden kuşatmayı kaldırdılar ve geri çekilmeye başladılar. Bu durumu fark eden Müslüman askerleri Haçlılar'ı takibe başladılar. Fırat'ın doğusundaki Haçlı askerleri ve Ermeniler korku içinde burada bulunan iki gemiye doluştular. İzdihamdan ve dengesiz yığılmadan ötürü bu gemiler battı ve içindekiler nehrin akıntısına kapılıp boğuldular (İbnü'l-Esîr, 1987/X: 388-390; Mateos, 1987: 238; Runciman, 1992/II: 95-99; Özaydın, 1990: 105-107). Haçlılar'ın geri çekilmesi üzerine Mevdûd, daha önce iktâ ettiği Harran'1 ve bu bölgelerin korumasını İlgazi’nin uhdesine bıraktı (Turan, 1980: 146). Ertesi yıl Temmuz 1111'de İlgazi oğlu Ayaz'ı bir miktar kuvvetle Mevdûd'un saflarında ikinci Urfa kuşatmasına gönderdi. Ancak Urfa'nın sağlam surları ve sıkı savunması nedeniyle Selçuklu ordusu yine bir netice elde edilemedi. Urfa'dan ümidini kesen Mevdûd, Joscelin'in hâkimiyetindeki Tell-Bâşir'e giderek buray1 kuşatma altına aldı. Ancak kırk beș gün süren bu kuşatmadan da istediği sonucu alamadı (İbnü'lEsîr, 1987/X: 388-390; İbnü'l-Adîm, 1954/II: 155 vd; Runciman, 1992/II: 95-99). Her ne kadar Müslümanların bu iki kuşatmada bir başarısı yokmuş gibi görünse de bu teşebbüsler, Haçlılar'ın kalplerine korku salmaya yetmiş ve onların kendi kabuklarına çekilip bölgede terör estirmelerini engellemiştir.

1113 yılında Kudüs Kralı I. Baudouin'in Dımaşk’a saldırı hazırlığında olduğu haberini alan Dımaşk Atabeyi Tuğtekin, Mevdûd ve İlgazi'den acil yardım istedi. Mevdûd yanına İlgazi’nin oğlu Ayaz ve Sincar Hâkimi Temirek'in kuvvetlerini alarak Fırat'ı geçti ve 18 Mayıs 1113'te Selemiye'de Tuğtekin'in kuvvetleri ile birlești. Bu gelişmeleri haber alan Kral Baudouin de Trablus Hâkimi Pons ile Antakya'nın yeni prinkepsi Roger de Salerne'i yardımına çağırdı. 30 Haziran günü iki ordu Dımaşk’ın güneyindeki Taberiye Gölü yakınlarında karşılaştılar. Yapılan çetin savaş Müslümanların zaferiyle sonuçlandı (İbnü’l-Esîr, 1987/X: 395). Ancak Müslümanların bu sevinci ve Haçlılar'dan kurtulma ümidi birkaç ay sonra mateme dönüştü. Çünkü Selçukluların muzaffer komutanı Mevdûd, 5 Eylül 1113 günü Cuma namazı için Tuğtekin ile beraber gittiği Dımaşk Ulu Camii'nden çıkarken bir Batınî (Haşhaşî) tarafından hançerlenerek öldürülmüştü (Mateos, 1987: 252; Ebû'l-Ferec, 1999/II: 352; Lewis, 1995: 87)

Sultan Muhammed Tapar, Mevdûd'un öldürülmesi üzerine Musul emirliğine Aksungur elPorsukî̀yi atadı. Ondan yeni bir ordu kurarak Haçlılar ile mücadeleye devam etmesini istedi. Sultanın emriyle hazırlanan Selçuklu ordusuna sultanın oğlu Mesud, Sincar Emiri Temirek ile Melikşah döneminde Halep emiri olan Aksungur el-Hacip'in oğlu genç İmadeddin Zengî de katılmıștı. Mardin Emîri İlgazi de bu orduya oğlu Ayaz kumandasında 300 kișilik bir kuvvet gönderdi (Süryani Mikhail, 1944/II: 79). Aksungur el-Porsukî’nin kumandası altında toplanan bu müttefik kuvvetler, 1114 yılında Urfa'yı iki ay boyunca kuşattılarsa da bir netice alamadılar. Haçlılar'a karşı bir başarı elde edilemediği için Selçuklu emirleri birbirlerini suçlamaya başladılar. $\mathrm{Bu}$ yüzden müttefik kuvvetler ana ordudan ayrılıp kendi bölgelerine döndüler. Başarısızlığının suçunu İlgazi'nin gelmemesine bağlayan Porsukî, Ayaz'ı tutukladı. Bu gelişmeler üzerine İlgazi yeğeni Belek ile Porsukî’nin üzerine yürüyerek onu mağlup etti ve oğlunu esaretten kurtardı (Mateos, 1987: 254; Süryani Mikhail, 1944/II: 80; İbnü'l-Esîr, 1987/X: 502-509; Ebû'l-Ferec, 1999/II: 354; Özaydın, 1990: 128-129). Yaşanan bu gelişmelere oldukça sinirlenen Sultan Muhammed Tapar, Şubat 1115'te Haçlılar'ı Suriye'den atma görevini Aksungur el-Porsukî'den alarak Hemedan Emiri Porsuk b. Porsuk'a verdi (Sevim, 1989: 219 vd; Merçil, 1999: 162-168). Porsuk komutasındaki Selçuklu ordusu, önce Kefertâb’1 Haçlılar'dan geri aldı. Daha sonra Maarratu'n-Nûmân üzerine yürüdü. Ancak Porsuk'un ordusu 14 Eylül 1115 günü Tell-Danis (Cebelü's-Semak) civarında Roger'ın ordusunun ani saldırısı sonucu feci bir bozguna uğradı. Bu zaferden sonra Haçlılar arasında itibar kazanan genç Roger, Kefertâb'1 da süratle Türkler'den geri aldı (Fulcherius Carnotensis, 2009: 192; İbnü'l-Adim, 1954/II: 175-176; Runciman, 1992/II: 132). Bu bozgunun ardından Muhammed Tapar, Suriye’yi Haçlılar'dan kurtarma girişimlerinden vaz geçerek yönünü ülkesindeki Bâtınîlerle mücadeleye çevirdi. 
1118 Nisan ayında Muhammed Tapar vefat etti. Kardeşi Sultan Sencer Büyük Selçuklu tahtına oturdu. Sencer'in muvafakatıyla Muhammed Tapar'ı 14 yaşındaki oğlu Mahmûd, Irak Selçuklu Sultanı oldu. Sultan Mahmûd tahta geçtikten sonra Meyyâfârikîn'i İlgazi’ye ikta olarak verdi (İbnü'l-Esîr, 1987/X: 592; İbnü'l-Ezrak, 1992: 31-32). Öte taraftan 1117 y1lında Halep Meliki Rıdvan ölmüş, yerine oğlu Alp Arslan geçmişti. Halep'i onun yerine yöneten Atabey Lü’lü el-Hadim Nisan 1118'de öldürülünce, Halep'in önde gelen kimseleri Haçlı tehlikesine karşı Mardin'deki Artuklu Emiri İlgazi'yi Halep'e davet ettiler ve şehrin yönetimine ona verdiler (Mateos, 1987: 268271; Azimî, 1988: 44-46; Süryani Mikhail, 1944/II: 50; İbnü'l-Esîr, 1987/X: 450, 478; İbnü’l-Adim, 1954/II: 164; Ebû'l-Ferec, 1999//II: 357; Ardıçoğlu, 1964: 37-41; Turan, 1980: 135, 147-151). İlgazi Halep’te asayişi temin ettikten sonra, başlangıçta Halep'i savunacak finans ve askerî gücü olmadığı için Haçlılarla anlaşma yoluna gitti (İbnü'l- Kalânisî, 2018: 83). Ancak Antakya Hâkimi Roger'in 1119 yılında Bizaa'yı zapt etmesi ile şehir üç taraftan Haçlılar'ın kuşatması altında kaldı. İlgazi, şehrin Haçlı tehdidi ile karşı karşıya olduğunu görünce, 1119 İlkbaharında yerine oğlu Hüsamettin Temurtaş'1 vekil bırakarak takviye kuvvetler getirmek üzere Mardin'e gitti. Burada Türkmenler, Kürtler ve Araplardan müteşekkil 20.000 kişilik güçlü bir ordu kurdu. Bu sırada Harput'ta bulunan yeğeni Belek'e de kuvvetleri ile beraber Halep'e gelmesi için haber gönderdi. Ardından müttefiki olan Dımaşk Atabeyi Tuğtekin'den de yardım istedi. Belek'in süratle gelmesinin ardından Antakya üzerine yürüdü. Haziran ayında Fırat'ı geçen İlgazi, Halep'in 25 km. güneyindeki Kınnesrin'de karargâhını kurdu ve burada Tuğtekin'in kuvvetlerinin gelmesini bekledi. Bu esnada kazandığı zaferlerle kendisine fazlasıyla güvenen Antakya Prinkepsi Roger, yardımını istediği Urfa, Kudüs ve Trablus Haçlı kuvvetlerinin gelmesini beklemeden İlgazi'nin karşısına çıktı. İlgazi ve Belek de Tuğtekin'in gelmesini daha fazla beklemediler ve 28 Haziran 1119'da Afrin'in Sarmeda (Şermeda) Ovası'nda Antakya Haçlı ordusuna karşı saldırıya geçtiler. Artuklu kuvvetleri Prinkeps Roger dâhil olmak üzere Antakya Haçlı ordusunu tümüyle kılıçtan geçirerek imha ettiler. Roger'ın cesedi kafası burun hizasından yarılmış olarak ölenler arasında bulundu ve Halep'e götürüldü. Franklar yaşadıkları bu korkunç olaya Ager Sanguinis (Kanlı Tarla) adını verdiler (Willermus Tyrensis, 1995: 77; İbnü'l-Esîr, 1987/X: 439-440; İbnü'l-Adim 1954/II: 189; Runciman, 1992/II: 121-128; Demirkent, 1994: 12-13; Holt, 1999: 30-31; Sevim, 2000: 89-90: Alptekin, 1991: 416).

Bu zaferin ardından Halife Müsterşid Billah, İlgazi’ye değerli hediyeler ve hilat göndererek kendisine Necmü'd-Din (Dinin Yıldızı) unvanını verdi. Şairler de onu öven şiirler kaleme aldılar (Azimli, 2008: 18). Bu savaşın Müslümanlar açısından olumlu yönü, Haçlılarla yapılan Belih Çayı Savaşı'ndan sonra onların uğradığı diğer bir büyük hezimet olması ve bu mağlubiyetin ilk kez sultanın Selçuklu ordusu tarafından değil de yerel bir emir tarafından gerçekleştirilmiş olmasıydı. Olumsuz açıdan bir diğer yönü ise bu zafer ile yetinen İlgazi'nin, içinde az bir kuvvet kalan Antakya'ya yürüyüp burasını kuşatma altına almayıp, Halep'e geri dönmesiydi. Nitekim bu sırada Antakya'da Patrik Bernhard kumandayı ele almış, şehirdeki Süryani, Ermeni ve Rum Hıristiyanların silahlarını ellerinden alarak onlara sokağa çıkma yasağı koymuştu. Çünkü yerli Hıristiyanlarla Frenkler arasındaki anlaşmazlık gün geçtikçe su yüzüne çıkmaya başlamış, yerliler batılıları kendi ibadetlerini küçümsemeleri ve kendilerini en ağır işlerde çalıştırmalarına karşı artık içten içe kızmaktaydılar. $\mathrm{Bu}$ durumu fark eden Patrik, yerli Hıristiyanların Müslümanlarla ittifak yapmalarından korkmakta, sadece papaz ve tacirleri silahlandırarak onlara surlarda gece gündüz nöbet tutturmaktaydı (İbnü'l-Esîr, 1987/X: 440; Runciman, 1992/II: 121-128; Demirkent, 1994: 1213; Holt, 1999: 30-31).

Bu sırada Roger'e yardım etmek üzere yola çıkmış bulunan Kudüs Kralı II. Baudouin, Urfa Kontluğu'na vekâlet eden Galeran du Puiset ve Trablus Kontu Pons, Haçlılar'ın hezimetini haber alınca yönlerini değiştirip Antakya'ya gelmişlerdi. 13 Ağustos 1119'da Kral Baudouin müttefik Haçlı kuvvetlerinin başına geçerek İlgazi tehlikesini ortadan kaldırmak üzere Antakya'dan hareket etti. Bu gelişmelerden habersiz olan İlgazi, müttefiki Tuğtekin ile Asi Irmağı'nın doğusundaki 
Haçlılar'a ait Esârib ve Zerdanâ Kalesi'ni ele geçirmiş, buradan Maarratu'n-Nûmân üzerine yürümekte idi. Haçlılar'ın ilerleyişini haber alınca buradan derhal geri döndü. 15 Ağustos 1119 günü iki ordu Tell-Danis’te, daha önce 1115 yılında Roger' in Selçuklu ordusunu bozguna uğrattığ yerde karşı karşıya geldiler. Yapılan savaşta her iki taraf da büyük kayıplar verince kuvvetlerini karşılıklı geri çektiler. Bu savaştan sonra hastalığı nükseden İlgazi, Mardin’e dönerken, Haçlılar da Antakya'ya çekildiler (İbnü'l-Esîr, 1987/X: 440; Runciman, 1992/II: 125-128; Alptekin, 1991: 182). Kudüs kralı ile İlgazi’nin Tell-Danis'deki çarpışmaları galibi belli olmayan bir savaş olarak sonuçlanmış, ancak her iki taraf da yanlarındaki esirlerle kendi bölgelerine döndüklerinde zaferle dönmüş gibi sevinçle karşılanmışlardır (İbnü'l-Esîr, 1987/X: 451).

1119 yılında Urfa Kontluğu'na atanan Joscelin, İslâm topraklarına karşı saldırı ve yağma hareketlerine girişti. Bunun üzerine İlgazi, Fırat'1 aşıp Tell Bâşir'den Keysun'a kadarki toprakları ele geçirerek buradaki Haçlı hâkimiyetine son verdi. Ardından, Urfa üzerine yürüyerek burayı kuşatma altına aldı. Urfa kuşatmasının dördüncü gününde, Sultan Mesûd'un elçileri gelerek; Gürcistan Kralı II. David (1089-1125)'in saldırısına uğrayan Nahcivan Meliki Tuğrul'un yardımına gitmesi gerektiğini bildirdiler. Kuşatmayı kaldıran İlgazi, Halep'in yönetimini oğlu Şemsü'd-Devle Süleymân'a bırakıp derhal Gürcistan seferine çıktı (İbnü’l-Ezrak, 1992: 33-34). İlgazi’nin yokluğunda Urfa Kontu Joscelin, Müslüman topraklarına saldırılarına devam etme firsatını elde etti. Kudüs Kralı Baudouin de Halep topraklarına saldırılarda bulunmaya başladı (Mateos, 1987: 265 268; İbnü'l-Esîr, 1987/X: 440, 451; Runciman, 1992/II: 127-123, 132; Demirkent, 1997: 75-76, 93). Halep ve Mardin'de bu olaylar yaşanırken Selçuklu Şehzadesi Tuğrul'a yardıma giden İlgazi, Ağustos 1121'de Tiflis yakınlarında Kıpçakların da desteğini alan Gürcü Kralı David'e gafil avlanarak mağlup oldu. Bu mağlubiyet İlgazi’nin katıldığg savaşlardaki aldığı tek mağlubiyet idi (İbnü'l-Esîr, 1987/X: 450; Paydaş, 2008: 211-220).

İlgazi’nin yokluğunda Halep valisi olan oğlu Süleymân, Joscelin ve Baudouin'in saldırılarını önleyemedi. Babasının Haçlılar'dan ele geçirdiği stratejik önemi olan Zerdanâ ve Esârib Kaleleri’ni iade etmek suretiyle onlarla sulh yoluna gitti. 1122'de yeğeni Belek ile Halep'e dönen İlgazi, Tuğtekin'in de desteği ile Zerdanâ'yı kuşattı ve bazı kaleleri yeniden ele geçirdi. Türkler bu sırada üzerlerine gelen Joscelin ve Baudouin'in kuvvetleriyle bir kez daha karşı karşıya geldiler. İki taraf birbirlerini bir süre kolladıktan sonra savaşmadan karşılıklı geri çekildiler (İbnü'l- Kalânisî, 2018; 85). Halep'e dönen İlgazi, başarılı bir yönetim sergilemeyen oğlu Süleymân’ı azletti ve onun yerine aynı isimdeki yeğeni Bedrü'd-Devle Süleymân b. Abdülcabbâr'ı Halep'e vali olarak atadı. Bir süre sonra hastalanınca da Halep'ten Mardin'e döndü. Burada biraz iyileşince Meyyâfârikîn'e gitmek üzere yola çıkan İlgazi'nin hastalığı, Evselü'l-Hine mevkiine geldiklerinde iyice attı ve 19 Kasım 1122'de Aculeyn Köyü'nde vefat etti. Onun ardından oğlu Şemsü'd-Devle Süleymân Meyyâfârikîn'e, Timurtaş da Mardin'e hâkim oldu (İbnü'l- Kalânisî, 2018: 86, 191; Mateos, 1987 : 272; İbnü'l-Esîr, 1987/X: 451; İbnü'l-Adîm, 1954/II: 206 vd; İbnü'l-Ezrak, 1992: 37-38; Alptekin, 1991: 415).

\section{Belek Gazi}

Tam künyesi Nuru'd-Devle Belek b. Behrâm b. Artuk olan Belek Gazi, Artuk Bey’in torunu, Sökmen ile İlgazi’nin yeğenidir. Babası Behrâm'ın muhtemelen bir savaşta hayatını kaybetmesi üzerine Artuk Bey torununu yanına alarak onu askerî, dinî ve siyasi alanda çok iyi yetiştirmiştir. Belek, 1096 yılında Kudüs'ü Fâtımîlere terk etmek zorunda kalan amcaları ile birlikte el-Cezire bölgesine gelmiştir (Alptekin, 1991: 415). Onların geldikleri bu coğrafya, o sırada Haçlılar ile Müslümanlar arasında cereyan eden savaşların en yoğun yaşandığı toraklardır. Artukoğulları da bölgede varlıklarını devam ettirebilmek ve Müslüman halkın koruyuculuğunu üstlenmek adına, Haçlılar ile amansız bir mücadele içerisine girmișlerdir. Belek'in Haçlılarla ilk ciddî karşılaşması 1101 'de onlara kaptırdığı Suruç önlerinde gerçekleşmiştir. Bu karşılaşmada amcası Sökmen ile birlikte Urfa Kontu Baudouin du Bourg'un Antakya'dan getirdiği takviye kuvvetlere karşı şehri 
daha fazla elde tutamayıp, Suruç'u terk etmek zorunda kalmışlardır (Mateos, 1987: 206 vd; İbnü’'Esîr, 1987/X: 267; İbnü’1 Adîm, 1954/II: 203; Runciman, 1992/II: 29-30; Ardıçoğlu, 1964: 37-38).

Suruç'u kaybettikten sonra Belek, Anadolu Selçuklu Sultanı I. Kılıç Arslan'ın çağrısı üzerine 1101 Yılı Haçlı Seferleri'ne katıldı. Burada gösterdiği cesaret ve kahramanlığı ile sultanın takdirini kazandı (İbnü'l-Kalânisî, 2018: 7; Ebû'l-Ferec, 1999/II: 351; Demirkent, 1996: 37-40). Anadolu'dan döndükten sonra amcası Sökmen'in yanına gelen Belek, 7 Mayıs 1104 günü Haçlılar'ın hezimete uğratıldıkları Belih Çayı Zaferi'nde de büyük yararlılıklar gösterdi (İbnü'l-Esîr, 1987/X: 303-304; Runciman, 1992/II: 32-33; Alptekin, 1991: 416). Sökmen'in, Trablus'a yardıma giderken yolda vefat etmesi üzerine, diğer amcası Necmeddin İlgazi'nin yanına giderek onun maiyetine girdi. Nisan 1110 yılında amcası İlgazi ile Musul Atabeyi Mevdûd'un saflarında, Urfa kuşatmasına ve Harran muhasarasına iştirak etti (Mateos, 1987: 225; Azimî,1988: 34; Willermus Tyrensis, 1995: 17-18; İbnü'l-Esir, 1987/X: 315-316; İbnü'l-Ezrak, 1992: 31; Runciman, 1992/II: 95-99). Bir ara amcası İlgazi ile arasında husumet bulunan Ahlat Şâh'ı Sökman el-Kutbî’nin eline esir düştü ve iki yıl Muş’ta Aydziats Kalesi'nde hapis kaldı (Alptekin, 1992: 402-403).

1112 'de Sökman el-Kutbî’nin ölümü üzerine serbest kalan Belek, Muş’tan el-Cezire bölgesine dönüp amcası İlgazi’nin yanına geldi. El-Cezire'ye henüz yeni gelmişti ki Harput Hâkimi Çubukoğlu Mehmed Bey'in vefat ettiği haberini aldı (Mateos, 1987: 243; İbnü'l-Esîr, 1987/X: 389; Turan, 1971: 152). Harput ve civarındaki iktidar boşluğundan istifade etmeyi düşünen Belek, amcasının müsaadesiyle bir ordu kurarak Harput üzerine yürüdü. Hısn-1 Ziyad (Harput Kalesi)'ı ele geçiremese de Çubukoğulları'na ait Palu, Çemişgezek ve Dersim (Tunceli) yörelerini zapt ederek, burada kendine ait bir beylik kurdu (Turan, 1980: 151). Bu sırada merhum I. Kılıç Arslan'ın eşi Ayşe Hatun, oğlu Tuğrul Arslan adına Malatya'yı yönetmekteydi (İbnü'l-Kalânisî, 2018: 158; İbnü'l-Esîr, 1987/X: 340-345; Ebû'l-Ferec, 1999/II: 345-346; Metin, 2017: 40; Turan, 1971: 108 vd). Ayşe Hatun Malatya'yı çevredeki beyliklere ve Haçlılar'a karşı daha fazla savunamayacağını anlayınca, bizzat Palu'ya gelerek Belek'ten oğlunun atabeyi olmasını rica etti. Belek, Tuğrul Arslan'ın atabeyliğini kabul etmekle kalmadı aynı zamanda Ayşe Hatun ile de nikâhlandı. Bu izdivacın ardından 1114 yılında Malatya'ya gelen Belek, bu bölgeleri beyliğine katmak suretiyle hâkimiyet sahasını genişletti (Mateos, 1987: 268-271; Ebû'l-Ferec, 1999/II: 357; Cahen, 1979: 101; Alptekin, 1992: 402 Yılmazçelik-Çelik, 2020: 280-297). 1115 yılında Harput'u bir miktar altın ve bazı yerlerin Çubukoğlu beyine bırakılması karşılı̆̆ında satın aldı (Mateos, 1987: 268-271; Azimî, 1988: 44-45; Süryani Mikhail, 1944/II: 50; İbnü’l-Esîr, 1987/X: 450, 478; Ebû'l-Ferec, 1999/II: 357; Ardıçoğlu, 1964: 37-41; Turan, 1980: 135, 147-151).

Bu sırada Belek'in bölgedeki etkinliğinden rahatsız olan Erzincan, Divriği ve Kemah bölgelerinin hâkimi Mengücekli İshak Bey, Belek'in Suriye'ye amcasının yanına gitmesini firsat bilerek, 1118 yılı sonlarında Dersim havalisini işgal etti ve Harput önlerine kadar ilerledi. Durumdan haberdar olan Belek, sert kış şartlarına rağmen süratle Halep'ten geri döndü ve 1119 Şubat'ında Mengücekli arazisine girerek Kemah ve Erzincan'ı işgal etti. Belek karşısında tutunamayacağını anlayan İshak Bey, geri çekilerek Trabzon Pontus-Rum Kralı Konstantin Gabras'a sığınmak zorunda kaldı (Ebû'l-Ferec, 1999/II: 356; Sümer, 1990: 3; Turan, 1971: 162). Mengücekli tehlikesini şimdilik bertaraf eden Belek, Halep'in Haçlılar'a karşı savunuculuğunu üstlenen amcası İlgazi’nin yardım çağrısı üzerine ordusu ile Halep'e gitti. 28 Haziran 1119'da Antakya Prinkepsi Roger'in ordusunun tümden imha edilmesinde (Ager Sanguinis: Kanlı Meydan Savaşı) etkin rol oynadı (İbnü'l-Esîr, 1987/X: 439-440; Willermus, 1995: 77; Runciman, 1992/II: 121-128; Alptekin, 1991: 416).

Müslümanların zafer kazanmasının ardından Mengücekliler ile mücadelesine kaldığı yerden devam etmek üzere Malatya'ya geri dönen Belek, Danişmendli Emir Gazi ile ittifak ederek Pontus Rumlarının üzerine yürüdü. 1120'de Şiran havalisinde Gabras ve İshak Bey'in kuvvetlerini ağır bir 
mağlubiyete uğrattığı gibi her ikisini de esir aldı (Süryani Mikhail, 1944/II: 51; Demirkent, 1994: 12-13; Sümer, 1990: 3; Cahen, 1979: 106). Belek'in bölgede elliden fazla kaleyi hâkimiyeti altına aldığı bu dönemde, Gerger Ermenileri onun Mengücekliler ile uğraşmasını firsat bilerek; Harput, Palu ve Malatya yörelerine sızıp eşkıyalık yapmaya, yağmalarda bulunmaya başlamışlardı (elAzharî, 2014: 288). Mengücekliler sorununu kökünden halletmek için uğraşan Belek, Gerger Hâkimi Ermeni Mihail'e haber gönderdi ve ondan eşkıyalık yapan Ermenileri yakalayıp cezalandırmasını istedi. Ancak Mihail çeşitli bahaneler ileri sürerek herhangi bir girişimde bulunmadı. Bunun üzerine Belek, Ocak 1121'de ağır kış şartları altında Fırat'ın donduğu bir sırada nehri ordusuyla geçip, Gubus civarında dağlık araziyi aştı. Gerger bölgesine ulaşan Belek'in askerleri, kendilerinin önünden kaçan Ermenilerin kardaki izlerini takip ettiler ve hepsini yakaladılar. Belek buradaki ahaliyi mal varlıklarıyla birlikte Hanzit Vadisi'ne tehcir etti ve bu sorunu daha fazla büyümeden halletmiş oldu (Süryani Mikhail, 1944/II: 51; Ebû'l-Ferec, 1999/II: 357; Demirkent, 1994: 26-27).

1121 yılında İlgazi, Tiflis’teki Müslümanların yardım çağrısı üzerine Halep'in başına oğlunu bırakarak Gürcistan üzerine yürümüş, ancak Gürcü Kralı II. David'in pususuna düşerek mağlup olmuştu. Bu sırada Halep'te babasının kudretine sahip olmayan Süleymân, Zerdanâ ve Esârib Kaleleri'ni Haçlılar'a geri vermek suretiyle onlarla sulh politikası izlemiş, İlgazi Halep'e dönünce yeğeni Belek'in desteği ve Dımaşk Hâkimi Tuğtekin'in gönderdiği kuvvetlerle Zerdanâ'yı ve bazı kaleleri Haçlılar'dan geri almıștı (İbnü'l-Esîr, 1987/X: 450; Turan, 1980: 150; Paydaș, 2008: 211220). Halep'te birkaç gün kalan ve bölgede asayişin tesisine katkıda bulunan Belek, Harput'a dönmek üzere Birecik güzergâhı üzerinden yola çıktı. Onun bölgeden geçeceği haberini alan Joscelin, kuzeni Birecik Senyörü Galeran de Puiset'in de desteğini alarak Türklerin izini sürmeye başladı. Gün boyu at süren Haçlılar, atlarını sulamak ve geceyi burada geçirmek düşüncesiyle Fırat Nehri'nin kenarındaki Dafdil Köyü civarında mola verdiler. Türk gözcüleri Haçlılar'ın yakınlarda olduğunu Belek'e haber verince Belek okçuları ve süvarileri ile Haçlı kuvvetlerinin etrafını sardı. 13 Eylül 1122 günü yağmurlu bir havada ansızın Türklerin ok yağmuruna tutulan Haçlılar, yerlerin çamurlu olmasından dolayı atlarını süremediler ve bir bir yere serildiler. Kısa süre içinde Joscelin ve Galeran'ın etrafında 60 şövalyeden başka ayakta duran kimse kalmamıştı. Türklerin bu baskını sonucu Joscelin, Galeran ve beraberlerindeki şövalyeler teslim alınmak suretiyle canlı ele geçirildiler (İbnü'l-Kalânisî, 2018: 86; Anonim Süryâni, 1933: 90). Belek bu kıymetli esirlerini yanına alarak önce Urfa'ya gitti. Urfa'nın ileri gelenlerine şehri kendisine teslim etmeleri halinde esirleri serbest bırakacağını vaat etti. Ancak Urfalılar onun bu teklifini kabul etmediler. Urfa'yı kuşatacak araçlara ve yeterli kuvvete sahip olmayan Belek, buradan Harput'a dönmek zorunda kald. Joscelin ve Galeran'ı Harput'un diğer şövalyeleri de Palu Kalesi'nin zindanlarına gönderdi (İbn Kalanisî, 2018: 86; Mateos, 1987: 271-272; Azimî, 1988: 45; Willermus Tyrensis, 1995: 87; İbnû'lAdîm, 1954/II: 156). Bu gelişmeler yaşanırken İlgazi, başarılı bir yönetim sergilemeyen oğlu Süleymân'ı Halep valiliğinden azletmiş, onun yerine yeğeni Bedrü’d-Devle Süleymân'ı atadıktan sonra Mardin'e giderken 19 Kasım 1122'de Meyyâfârikîn yakınlarında Evselü'l-Hine mevkiinde vefat etmişti. Belek amcasının Meyyâfârikîn'de vefat ettiği haberini alınca Kasım ayı sonlarında Halep'e gelerek burada taziyeleri kabul etti (Azîmî, 1988: 44 vd; Mateos, 1987: 268-72; İbnü'l-Esîr, 1987/X: 440,451; Willermus Tyrensis, 1995: 78; Runciman, 1992/II: 123,132; Sevim, 1962: 90). İlgazi’nin ölümüyle Artukluların liderliği ve bölgedeki Haçlılar ile mücadelenin yükü Belek'in omuzlarına kalmış oluyordu.

Kudüs Kralı Baudouin, Trablus'ta bulunduğu sırada Joscelin ve Galeran'ın Belek'e esir düştüğü ve Belek'in Urfa üzerine yürümekte olduğu haberlerini aldı. Urfa'nın başsız kalması halinde şehrin Belek'in eline geçeceğini düşünen Baudouin, derhal Urfa'ya giderek buranın idaresini uhdesine ald1 (Runciman, 1992/II: 133-134; Demirkent, 1994: 32-37; Turan, 1980: 151-152; Alptekin, 1991: 417; Ardıçoğlu, 1964: 39-40). Tüm bunlar yaşanırken Gerger'in Ermeni Hâkimi 
Mihail, Belek'in üstüne gelmesi durumunda Gerger'i savunamayacağını bildiği için Urfa'da bulunan Kudüs kralına Gerger'in hâkimiyetini teklif etti. Teklifi kabul edilince Mihail derhal Gerger'den ayrılıp kendisine verilen Dülük'e gitti. Onun Gerger'den ayrıldığını haber alan Belek, burayı ele geçirmek üzere 1123 yılı Nisan ayının başlarında yola çıktı. Kudüs Kralı II. Baudouin de Belek'in yola çıktığından habersiz, 18 Nisan 1123'de Gerger'i teslim almak üzere ordusu ile Antakya'dan yola çıkmıştı. Bu sırada Belek'in gözcüleri Haçlılar'ın Samsat yakınlarında karargâh kurdukları haberini getirdiler. Belek ani bir saldırı ile Haçlı ordusunu kılıçtan geçirdi. Kral Baudouin de tıpkı Joscelin gibi yanında kalan az sayıdaki şövalye ile birlikte Belek'e teslim olmak zorunda kaldı. Belek onları da yanına alarak Gerger'e gitti ve şehri kuşattı. Kralın esir düştüğünü gören Gerger garnizonu 25 Nisan'da şehri teslim etmek zorunda kaldı. Şehirde bir Türk garnizonu kuran Belek, esirleri yanına alıp Harput'a götürdü ve onları da zindana attı (Mateos, 1987: 272-273; İbnü’lEsîr, 1987/X: 468-469, 483-485; İbnü'l-Adîm, 1954/II: 210; Ünal, 1989: 16). Öte taraftan Kudüs Kralı II. Baudouin, Urfa Kontu Joscelin, Birecik Senyörü Galeran ve pek çok Haçlı komutanı ile şövalyenin tutsak edilmeleri üzerine, Kudüs patriği ve kilise ileri gelenleri Akkâ'da acil bir toplantı düzenlediler. Bu toplantı sonucunda kralları serbest kalıncaya kadar Kaysâriyye ve Saydâ Senyörü Eustache Garnier'i Haçlı devletlerinin naibi (coonnetable) olarak seçtiler (Willermus Tyrensis, 1995: 89).

Belek'in Halep ve civarındaki yokluğundan istifade eden Haçlılar, bölgedeki saldırılarını devam ettirince Halep Hâkimi Bedrü'd-Devle Süleymân, Esârib Kalesi’ni teslim etmek suretiyle onlarla sulh yaptı. Bunu öğrenen Belek derhal Harput'tan çıkarak güneye yöneldi. Yanında Baudouin ve Galeran da vardı. Harran'a gelerek önce buranın hâkimiyetini uhdesine aldı. Kralı ve Galeran'1 Harran zindanlarına atarak buradan Halep'e yöneldi. Kısa bir direnişin ardından amcazadesi Süleymân Halep'i ona teslim etmek zorunda kaldı. Halep'te bir süre kalarak burada Melik Rıdvan'ın kızı Ferhunde Hatun ile evlenen Belek, bu izdivacın ardından Haçlılar ile mücadelesine vakit kaybetmeden devam etti. Belek topladığı kuvvetlerle 7 Ağustos 1123 'te Haçlılar'ın elinde bulunan el-Bâre Kalesi'ni ele geçirdi. 11 Ağustos'ta Kefertâb'ı kuşattığı sırada Harput'tan aldığı şok bir haberle sarsıldı (Azîmî, 1988: 46,57; İbnü'l-Âdîm, 1954/II: 210-213; İbnü'l-Esîr, 1987/X: 483-485; Mateos, 1987: 237-274; Ebû'l-Ferec, 1999/II: 358). Aldığı habere göre 'Besni'den gelen bazı Ermeniler yoksul köylüler kılığında Harput Kalesi’ne girmiş, kaledeki Ermenilerin de yardımıyla o sırada yemekte olan kale komutanı ve askerleri öldürmüş ve Haçlı liderlerini serbest bırakıp kaleyi ele geçirmişlerdi.” (Fulcherius Carnotentis 2009: 224-225, Anonim Süryâni, 1933: 90 vd). Bu süreçte Ermenilerin kaleyi ele geçirdikleri haberini alan Harput'un Müslüman halkı ellerine geçirdikleri kılıç, kama, tırmık, balta vb. aletler ile kaleyi kuşatmış, derhal Belek'e haber vermek üzere ulaklar yola çıkarmış ve gece gündüz nöbet tutarak kaleden kimsenin çıkmasına firsat vermemişlerdi. Sadece Joscelin iki-üç kişi ile birlikte, yardım getirmek amacıyla gece karanlığından istifade edip gizlice kaleden kaçmayı başarabilmişti (Willermus Tyrensis, 1995: 90; Anonim Süryâni, 1933: 94-95).

Belek Gazi olan biteni öğrenir öğrenmez süratle Harput Kalesi’ne ulaştı. Harput Kalesi’ni kuşatma altına alarak, Kral Baudouin'e teslim olmaları halinde canlarını bağışlayacağına dair söz verdi. Başlangıçta Joscelin'den yardım geleceğini uman Haçlılar bu teklifi reddettiler. Ancak Belek'in kulelerden birinin altına tünel kazdırıp çökertmesi üzerine kralın elçisi sıfatıyla Galeran, Belek'e gelip canlarının bağışlaması şartıyla teslim olacaklarını söyledi. Belek'in söz vermesi üzerine kaledekiler teslim oldular. 6 Eylül 1123'te kaleye giren Belek, kendisine ihanet eden Ermenileri affetmeyip idam ettirdi. Haçlı liderlerini ve şövalyelerini tekrar eski zindanlarına gönderdi (Fulcherius Carnotentis 2009: 225; Mateos, 1987: 274; Anonim Süryâni, 1933: 93). Öte taraftan Joscelin, Kudüs'ten topladığı ordu ile Harput üzerine yürürken, kalenin yeniden Belek’in eline geçtiğini öğrendi. Bunun üzerine Harput'a gitmekten vaz geçti ve bölgedeki Müslümanlara karşı adeta terör estirerek Belek'ten intikam almaya çalıştı (Azimî, 1988: 46; Mateos, 1987: 274). 
Joscelin'in bölgede yağma ve katliamlarda bulunup Müslümanlara büyük eziyetler çektirdiği haberini alan Belek, 1124 Ocak ayında Harput'tan yola çıkıp Halep'e geldi. Halep’te terör estiren Şiî İsmailîler (Bâtınîler/Nizârîler)'e karşı bir takım tedbirler aldı. Halep sorumlusu Bâtınî şeyhinin dâisi Behrâm'ın üzerine yürüyerek onu tutukladı. Halep’teki Bâtınîler ondan korktukları için evlerini ve eşyalarını satarak Halep'i terk ettiler (İbnü'l-Adîm, 1954/II, 216). Haçlılar karşısında gösterdiği kahramanlık ve başarılarından dolayı Sultan Mahmûd, ona “Gazi” unvanı ile Halep'in menşurunu verdi (el-Azharî, 2014: 290). Bâtınîler sorunu da halleden Belek Gazi, Haçlılar’a karş1 büyük bir seferberliğin hazırlığını yapmaya başladı ve bölgedeki tüm Müslümanları cihada davet etti. Amcaoğulları; Dâvûd, Süleymân ve Timurtaş aile büyüğü saydıkları Belek'in yanında yer aldılar. Artuklu ailesinden başka Dımaşk Atabeyi Tuğtekin ile Musul Emiri Aksungur Porsukî de ona önemli miktarda destek kuvvet gönderdiler (Mateos, 1987: 237-274; Azîmî, 1988: 46,116; İbnü'l-Esîr, 1987/X: 485; İbnü'l-Âdîm, 1954/II: 217; Ebû'l-Ferec, 1999/II: 358; Sevim, 1961: 573). Güçlü bir ordu kuran Belek, ilk hedef olarak Haçlılar'ın elindeki Azaz Kalesi’ni kuşattı. Haçlılar'ın Azaz'a yardıma gelmesi ve kaledeki muhafızların aniden huruç etmeleri üzerine Belek, iki ateş arasında kalmamak için ordusunu geri çekti (İbnü'l-Esir, 1987/X: 488; Runciman, 1992/II: 136; Ardıçoğlu, 1964: 65). Bu gelişmeler yaşanırken, yıllardır kendisinin müttefiki olan Menbiç Hâkimi Hassan b. Gümüştekin kendisine destek kuvvet göndermedi. Belek onun ihanet ederek Haçlılarla işbirliği yaptığı duyumunu alınca, Nisan 1124'te Menbiç'i zapt etmek üzere Halep hâkimi olan kuzeni Timurtaş'1 görevlendirdi. Timurtaş, Tell-Başir'e giderek savaş ganimetleri toplamak vaadiyle Hassan'ı kaleden çıkarttı ve tutukladı. Palu Kalesinin zindanlarına gönderilen Hassan, Belek öldükten sonra 1125 'te fidye karşılığı Dâvûd b. Sökmen tarafindan serbest birakılınca Menbiç'e dönebildi. Hassan'ın tutuklandığını gören kardeşi Îsâ, askerleriyle iç kaleye çekilerek savunmaya geçti. Joscelin'e haber göndererek kendilerine yardıma gelmesi durumunda şehri ona vereceğini vaat etti. Bu arada Azaz'dan hareket eden ve kısa süre sonra Menbiç önlerine gelen Belek iç kaleyi kuşatma altına aldı (Mateos, 1987: 277; Azimî, 1988: 47; İbnü'l-Adîm, 2011: 83,89-90; Ebû'l-Ferec, 1999/II: 358; Runciman, 1992/II: 136; Demirkent, 1994: 47; Turan, 1980: 145 vd; Erdem, 2018: 203).

Urfa Kontu Joscelin, Maraş ve Keysun Senyörü Geoffroy (Keşiş Godfrey) güçlerini birleştirerek Menbiç'i Belek'in elinden kurtarmak için harekete geçtiler. 5 Mayıs 1124'de Menbiç önlerinde gerçekleşen şiddetli savaşı Belek Gazi'nin ordusu kazandı (Runciman, 1992/II: 134-136; Demirkent, 1994: 33,43,50). Bu sırada Doğu Akdeniz kıyılarında Müslümanların elinde kalan son şehir olan Sûr'un, Haçlılar'ın saldırısına uğradığı haberi geldi. Belek, Sûr'a doğru hareket etmeden önce, 6 Mayıs 1124’te Menbiç iç kalesinin ele geçirilmesi için yeğeni Timurtaş’1 görevlendirdi. Zırhını üzerinden çıkarıp Timurtaş'a ve diğer komutanlara kuşatma ile alakalı emir ve direktifler verdiği sırada, surlardan atılan bir ok sırtına saplandı (Mateos, 1987: 277-278; İbnü'l-Âdîm, 1954/II: 219). Rivayete göre Belek Gazi, oku bizzat çıkarıp kırmış son olarak ağzından dökülen, "Bu ok bütün Müslümanlara vurulmuş bir darbedir." sözleriyle Müslümanların duygularına tercüman olmuştur (İbnü'l-Esîr, 1987/X: 489; Ebû'l-Ferec, 1999/II: 358; Yınanç, 2002: 472; Demirkent, 1994: 51; Turan, 1980: 152).

Belek'in naaşı 7 Mayıs 1124'te Timurtaş tarafından Halep'e götürülerek Makam-1 İbrâhîm civarında defnedildi (Artuk, 1947: 127-135). Belek'in çocuğu olmadığı için amcazadeleri Artuklu mirasını aralarında paylaştılar. Bu paylaşım sonucu Meyyâfârikîn ve Harput İlgazi'nin büyük oğlu Süleymân'ın, Mardin ve Halep küçük oğlu Hüsameddin Timurtaş'ın, Hasankeyf ve Palu Sökmen'in oğlu Dâvûd'un hâkimiyetine geçti (Azimî, 1988: 44; İbnü'l-Esîr, 1987/X: 450; İbnü'l-Adîm, 2011: 83; Runciman, 1992/II: 131-132; Turan, 1980: 150). Haziran 1124’te Urfa Kontu Joscelin ve Kudüs Kraliçesi Morphia, Munkizoğulları aracılığı ile Timurtaş ile irtibat kurarak Kral Baudouin'in serbest bırakılması hususunda anlaştılar. Buna göre Esârib, Zerdanâ, el-Cezire, Kefertâb ve Azaz Timurtaş'a bırakılacak, Haçlılar, Dübeys b. Sadaka ile ittifakı sonlandıracak, esirler için 20.000 
dinarı peşin olmak üzere 80.000 dinar fidye ödenecekti. Anlaşma gereği Kral Baudouin Eylül 1124 'te Müslümanların esaretinden kurtuldu. Serbest kalan Baudouin, Azaz'nn ve diğer kalelerin teslim edilmesine Antakya patriğinin müsaade etmediğini bahane ederek verdiği bütün sözlerden döndü. Ardından Dübeys ile de ittifak kurarak Müslümanlara karşı saldırılarına kaldığı yerden devam etti. Sûr şehri yöneticileri de Temmuz 1124'te şehri Kral Baudouin'e teslim etmek zorunda kaldılar (Mateos, 1987: 278-279; Azîmî, 1988: 48; İbnü'l-Adîm, 1954/II: 221-223; Ebû'l-Ferec, 1999/II: 358; Gibb, 1955: 452; Runciman, 1992/II: 141; Demirkent, 1994: 58; Sevim, 1961: 575576).

\section{SONUÇ}

Artuk Bey'in oğulları Sökmen ve İlgazi, Haçlılar'ın İslam dünyası için büyük bir tehlike oluşturduğu ve Büyük Selçuklu Devleti ordusunun sahneden çekildiği bir dönemde, Haçlllar ile mücadelenin öncüleri olmuş, onların Anadolu ve Suriye'deki yayılmalarının önüne aşılmaz bir set çekmişlerdir. Sökmen'in Çökürmüş ile ittifak ederek 1104 yılında Harran'da Belih Çayı civarında müttefik Haçlı kuvvetlerini hezimete uğratıp Urfa Kontu Baudouin ile Tell-Bâşir Hâkimi Joscelin'i esir almaları, Haçlılar'ın Urfa'nın doğusuna doğru yayılmalarını önlemiş, onların saldırıdan savunmaya çekilmelerine sebep olmuştur. Sökmen'in vefatından sonra İlgazi ve yeğeni Belek'in, Müslüman gönüllülerin de katılımıyla 1119 yılında Sarmeda Ovası'nda Antakya Haçlı Prinkepsi Roger'i ordusuyla beraber ortadan kaldırması, bölge Müslümanlarını sevince ve ümitlenmeye sevk ederken, Haçlılar'ı büyük bir korku ve endişeye düşürmüştür. Haçlılar çağının en önemli destansı kahramanlarından birisi olan Belek Gazi, amcaları vefat edince Haçlılarla mücadelenin başkomutanlığını üstlenmiştir. Sökmen, İlgazi ve yeğenleri Belek Gazi döneminde Haçlılar ile yaşanan gelişmeler Anadolu Türk tarihinin seyri açısından da önemli sonuçlar doğurmuştur.

Özellikle Artuk Bey'in torunu Belek Gazi, kudreti, kahramanlığı, adaleti, dindarlığı, nizam ve asayişi sağlamadaki başarısı ile Türk-İ̀slâm dünyasının sevgi ve saygısını kazanmıştır. Bu yüzden

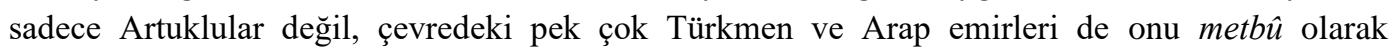
tanımışlardır. Neredeyse tüm hayatı Haçlılar ile mücadele etmekle geçmiş bulunan Harput Artuklu Hükümdarlığı'nın kurucusu Belek Gazi, Urfa Haçlı Kontu Joscelin, Birecik Hâkimi Galeran ve Kudüs Kralı II Baudouin'in kuvvetlerini bozguna uğratıp onları esir etmekle Haçlılar'ın âdeta kolunu kesmiş, onları bulundukları alana hapsederek İslâm coğrafyasında daha geniş alanlara yayılmalarını önlemiştir. Haçlılar'ın saldırı ve yağmalarından mustarip olan bölge insanları onun sayesinde rahat bir nefes almışlardır. Haçlılar’a karşı verdiği başarılı mücadelenin yanı sıra Belek, Halep'teki Bâtınîler (Haşhaşîler) ve gizli örgütleri de etkisiz hale getirmiştir. Esas hedefi, Haçlılar'ı İslâm dünyasının kalbinden tamamen söküp atmak olan Belek Gazi'nin zamansız ölümü onun bu hedefinin akamete uğramasına sebep olmuştur. Nitekim onun kendisini vuran oku kendi eliyle çıkarıp "Bu ok bütün Müslümanlara vurulmuş bir darbedir." sözü bu trajik sonun en anlamlı ifadesidir.

Belek Gazi’nin vefatının ardından, Artukoğulları bölünüp küçülmüş ve kendi kabuklarına çekilerek Haçlılar ile cihadı bırakmışlardır. Esir edilen Haçlı liderleri Artuklu beyleri tarafından etkili bir koz olarak kullanılmamış, küçük menfaatler karşılığında serbest bırakılmışlardır. Artukoğullarının bölgede etkinliğinin azalmasının ardından Suriye ve Doğu Anadolu'da da bazı siyasî dengeler değişmiş, Gürcüler savunmadan çıkıp Doğu Anadolu topraklarına karşı taarruza geçerken, Danişmendliler de korumasız kalan Malatya'yı kendi topraklarına katarak bölgede hâkim güç olmuşlardır. Haçlılar ile mücadele bir süre duraksamış gibi görünse de Artukoğullarının mücadele ruhu Müslümanlar arasında yeni bir uyanışa sebep olmuş, bir süre sonar, Danişmendliler, Zengîler, daha sonra da Eyyûbîler, Haçlılar'a karşı girişilen mücadelenin bayrağını devralmışlardır. 


\section{KAYNAKÇA}

Alptekin, C. (1991). Artuklular. DİA. C. III. İstanbul: TDV Yayınları. s. 415-419.

Alptekin, C. (1992). Belek b. Behram. DİA. C. V. İstanbul: TDV Yayınları. s. 402-403.

Alptekin, C. (1992). Büyük Selçuklular, Irak Selçukluları, Dımaşk Atabegliği, Musul Atabegliği. DGBIT, C. VII, Çă̆ Yayınları. s. 402-403.

Anna K. (1996). Alexiad. Anadolu'da ve Balkan Yarımadası'nda Imparator Alexias Komnenos Dönemi’nin Tarihi, Malazgirt'in Sonrası. İstanbul: İnk1lap Kitabevi.

Anonim Süryâni Vekâyinâmesi, (1933). The First and Second Crusades from an Anonymous Syriac Chronicle. (Çev. Tritton, A.S.), Journal of The Royal Asiatic Society, C. XV, s. 69-101.

Ardıçoğlu, N. (1964). Harput Tarihi. İstanbul: Harput Derneği Yayınları.

Artuk, İ. (1947). Artukoğlu Emir Balak ve Mezar1. Belleten, C.XI, S. 41, s. 129-135.

Artuk, İ. (1988). Artuk Bey. Kültür ve Turizm Bakanlığı Yayınları, Türk Büyükleri Dizisi: $104,1$.

Azîmî, (1988). Azîmî Tarihi; Selçuklularla İlgili Bölümler (Derleyen: Ali Sevim). Ankara: Türk Tarih Kurumu Yayınları.

Azimli, M. (2008). Artukluların Kuruluşu ve İlk Artuklu Emiri Necmeddin İlgazi'nin Siyasi Faaliyetleri. I. Uluslararası Artuklu Sempozyumu Bildirileri. Mardin. C. 1, s. 11-20.

Bailly, A. (2006). Bizans Tarihi II. (Çev. Haluk Şaman). İstanbul: Nokta Kitap.

Cahen, C. (1979). Osmanlılardan Önce Anadolu'da Türkler. İstanbul: E Yayınları.

Fulcherios C. (2009). Kudüs Seferi. (Çev. İlcan Bihter Barlas). İstanbul: IQ Yayınları.

Demirkent, I. (1990). Urfa Haçlı Kontluğu Tarihi I(1098-1118). Ankara: Türk Tarih Kurumu Yayınları.

Demirkent, I. (1994). Urfa Haçlı Kontluğu Tarihi II (1118-1146). Ankara: Türk Tarih Kurumu Yayınları.

Demirkent, I. (1996). Türkiye Selçuklu Hükümdarı Sultan I. Kılıç Arslan. Ankara: Türk Tarih Kurumu Yayınları.

Demirkent, I. (1997). Haçlı Seferleri Tarihi. İstanbul: Dünya Yayıncılık.

Demirkent, I. (1995). 1101 Yılı Haçlı Seferleri. Prof. Dr. Fikret Işıltan'a 80. Doğum Yılı Armağanı. İstanbul: İ.Ü. Edebiyat Fakültesi Yayınları.

Ebû'l-Ferec, G. (Bar Hebraeus), (1999). Abû'l-Farac Tarihi II (çev. Ömer Rıza Doğrul). Ankara: Türk Tarih Kurumu Yayınları.

El-Azharî, T. K. (2014). The Policy of Balak The Artukids Against Muslims and Crusaders. A Turkmen Identity Dilemma in the Middle East 1090-1124. International Journal of Humanities and Social Science, C. 4, S. 4, s. 286-293. İlmiyye.

En-Nuveyrî, Ş. A. (1992). Nihayetü'l-Ereb fî Funûni'l-Edeb, C. I-XXXXII, Daru'l-Kütübi'l-

Erdem, İ. (2018). Haçlılar İle Mücadelede Menbic ve Emir Belek. Ankara Üniversitesi, Dil ve Tarih Coğrafya Fakültesi Tarih Araştırmaları Dergisi, C. 37, S. 64, s. 191-204.

Eyice, İ. (2001), İznik. DİA, C. XXIII, İstanbul: TDV Yay, s. 543-545. 
Gibb, H. A. R. (1955). Zengi and The Fall of Edessa. A History of The Crusades, C. I, (Ed. Kenneth M. Setton). Philedelphia: The University of Pennsylvania Press, s. 449-462.

Holt, P. M. (1999). The Age of The Crusades, The Near East from The Eleventh Century to 1517, (Çev. Özden Arıkan). İstanbul: Tarih Vakfı Yurt Yayınları.

İbnü’l Adîm, K. (1954). Zübdetü'l-Haleb min Tarih-i Haleb II. (Derleyen: Sami Dehan). Ankara: Türk Tarih Kurumu Yayınları.

İbnü'l Adîm, K. (2011). Buğyat at-Talab fî Târîh Halab (Derleyen: Ali Sevim,). Ankara: Türk Tarih Kurumu Yayınları.

İbnü'l-Cevzî, S. (1992). Miratu'z-Zaman fi Tarihi'l-Ayan (Derleyen: Ali Sevim). Ankara: Türk Tarih Kurumu Yayınları.

İbnü'l-Esîr, İ. (1987). İslâm Tarihi: El-Kâmil fi't-Tarih Tercümesi X (Çev. Ahmet Ağırakça -Abdülkerim Özaydın). İstanbul: Bahar Yayınları.

İbnü'l-Ezrak, A. (1992). Tarih-i Meyyâfârikîn ve Amid (Artuklular Klsmı). (Derleyen: A. Savran). Erzurum: Atatürk Üni. Fen-Edb. Fak. Yayınları, s. 29-38.

İbnü'l-Kalânisî, H. (2015). Şam Tarihine Zeyl - I. ve II. Haçlı Seferleri Dönemi (Çev. Onur Özatağ). İstanbul: İş Bankası Kültür Yayınları. Basımevi.

Köymen, M. A. (1982). Selçuklu Devri Türk Tarihi. Ankara: Dil ve Tarih Coğrafya Fakültesi

Küçüksipahioğlu, B. (2007). Trablus Haçlı Kontluğu Tarihi. İstanbul: Arkeoloji ve Sanat Yayınları, 77.

Kütük, A. (2018). Unutulan Zafer: Harran Savaş1 (1104) Ve Türk-İslâm Tarihindeki Yeri. İslâm Tarihi Ve Medeniyetinde Harran I (Ed. Kasım Şulul ve dğr.). Ankara: Berikan Yayınları, s. 157-173.

Lamb, H. (2010). The Crusade: Iron Men and Saints: Haçlı Seferleri: Demir Adamlar ve Azizler (Çev. Gaye Yavuzcan). İstanbul: İlgi Kültür Sanat Yayınları.

Lewis, B. (1995). Haşişiler (Çev. Ali Aktan). İstanbul: Sebil Yayınevi.

Metin, T. (2017). Sultanlığı Meşrûiyet Kazanmamış Bir Selçuklu Şehzadesi: Tuğrul Arslan. Selçuk Üniversitesi Selçuklu Araştırmaları Dergisi, S. 6, s. 40.

Merçil, E. (1999). Haçlı Seferleri Sırasında Büyük Selçuklu Devleti’nin Durumu. Uluslar Arası Haçlı Seferleri Sempozyumu (23-25 Haziran 1997). Ankara: Türk Tarih Kurumu Yayınları, s. 83-90.

Müneccimbaşı, A. (2001). Camiu'd-Düvel: Selçuklular Tarihi II (Derleyen: Ali Öngül). İzmir: Akademi Kitabevi.

Özaydın, A. (1990). Sultan Muhammed Tapar Devri Selçuklu Tarihi (1105-1118). Ankara: Türk Tarih Kurumu Yayınları.

Özaydın, A. (1992). Danişmendliler. DGBİT, C. VIII, İstanbul: Çă̆ Yayınları, s. 121-138.

Paydaş, K. (2008). Artuklular ve Gürcüler. I. Uluslararası Artuklu Sempozyumu Bildirileri I (Ed. İbrahim Özcoşar), Mardin: Mardin Valiliği Kültür Yayınları, s. 211-220.

Refik, A. (h. 1327). Büyük Tarih-i Umumî VI. Kitaphane-i İslâm ve Askerî - İbrahim Hilmi, İstanbul: Matyosyan, s. 23. 
Runciman, S. (1992). Haçlı Seferleri Tarihi I-II (Çev. Fikret Iş̧ıltan) Ankara: Türk Tarih Kurumu Yayınları.

Sevim, A. (1989). Suriye ve Filistin Selçukluları Tarihi. Ankara: Türk Tarih Kurumu Yayınları.

Sevim, A. (1990). Ünlü Selçuklu Komutanlarl; Afşsin, Atsız, Artuk ve Aksungur. Ankara: Türk Tarih Kurumu Yayınları.

Sevim, A. (1961). Temürtaş'ın Halep Hâkimiyeti. Belleten, C. XXV, S. 100, s. 571-594.

Sevim, A. (1962). Artukoğlu Sökmen'in Siyasî Faaliyetleri. Belleten, C. XXVI, S. 103, s. 501-520.

Sevim, A. (1962). Artukoğlu İlgazi. Belleten, C. XXVI, S. 104, s. 649-687.

Sevim, A. (1990). Artukların Soyu ve Artuk Beyin Siyasî Faaliyetleri, Belleten, C. XXVI, S. 101, 121-146.

Sevim, A. (1991). Artuk b. Eksük. DİA, C. III, İstanbul: TDV Yayınları, s. 414.

Sevim, A. (2000). İlgazi, Necmeddin. DİA, C. XXII, İstanbul: TDV Yayınları, s. 89-90.

Sümer, F. (1990). Selçuklular Devrinde Doğu Anadolu'da Türk Beylikleri, Ankara: Türk Tarih Kurumu Yayınları.

Süryani M. (1944). Khronik (1166-1199), (Çev. H. Andreasyan). Ankara: Türk Tarih Kurumu Yayınları.

Turan, O. (1971). Selçuklular Zamanında Türkiye Siyasi Tarihi, Alp Arslan'dan Osman Gazi’ye (1071-1318). İstanbul: Nakışlar Yayınevi.

Turan, O. (1980). Artuklular. Doğu Anadolu Türk Devletleri Tarihi. İstanbul: Nakışlar Yayınevi.

Tyrensis, W. (1995). Historia Rerum in Partibus Transmarinis Gestarum, XI. ve XII. Kitap, (çev. Ebru Altan, İstanbul Üni., SBE, Yüksek Lisans Tezi), 17-18,77-89.

Urfalı Mateos, Urfalı Mateos Vekâyinâmesi (952-1136) ve Papaz Grigor'un Zeyli (11361162), (1987). Ankara: Türk Tarih Kurumu Yayınları.

Ünal, M. A. (1989). XVI Yüzyılda Harput Sancă̆ı. Ankara: Türk Tarih Kurumu Yayınları.

Yıldız, D. H. (1990). Anadolu Selçuklu Devleti: Türk Dünyası El Kitabı III, Ankara: Türk Kültürünü Araştırma Enstitüsü Yayınları.

Yılmazçelik, İ. - Çelik, S. (2020). Malatya Melikesi Ayşe Hatun'un Belek Gazi ile İzdivacı. Malatya'nın Fethi ve Uluslararası Danişmendliler Sempozyumu (19-21 Eylül 2018). Malatya: İnönü Üni. Yayınları, s. 280-297.

Yınanç, M. H. (1944). Türkiye Tarihi Selçuklular Devri. İstanbul: İstanbul Üniversitesi Yayınları.

Yınanç, M. H. (2002). Belek. İA., C. II, Ankara: MEB Yayınları, s. 468-473. 